\title{
Prevention of UVB radiation-induced oxidative stress in mice by topical administration of Azadirachta indica (neem) extract
}

\author{
Renata Micheli Martinez¹ , Clara Ruiza de Souza ${ }^{1}$, Cristina de Paula Barros de Melo', \\ Marcela Maria Baracat ${ }^{1}$, Nilton Syogo Arakawa ${ }^{1}$, José Carlos Duarte ${ }^{1}$, Waldiceu Aparecido Verri Jr², Rúbia \\ Casagrande ${ }^{1}$, Sandra Regina Georgetti ${ }^{1 *}$ \\ 'Departamento de Ciências Farmacêuticas, Universidade Estadual de Londrina (UEL), Londrina, PR, Brasil \\ 2Departamento de Patologia, Universidade Estadual de Londrina (UEL), Londrina, PR, Brasil \\ *Corresponding author: sangeorgetti@gmail.com; srgeorgetti@uel.com.br
}

\begin{abstract}
Neem tree (Azadirachta indica A. Juss. fam. Meliaceae) has been extensively employed to combat diverse pathologies. Moreover, it has been described that its leaf extract present anticarcinogenic action. Thus, the neem extract (NE) chemical and antioxidant properties was evaluated, and also, the capacity of two dermatological formulations incorporated with neem extract (F1 and F2) to avoid oxidative UVB-induced skin injury in hairless mice. NE constituents were investigated and free radical scavenging ability were determined by different methods in vitro. Skin from mice treated with F1 and F2 and submitted to UVB radiation were tested for different parameters of inflammation and oxidative injury. Results show that the NE polyphenol and flavonoid content were 135.30 and $37.12 \mathrm{mg} / \mathrm{g}$, respectively. High performance liquid chromatography (HPLC) results demonstrated the existence of azarachtin, rutin, ursolic acid and tannic acid. NE presented scavenging ability by ABTS radical, ferric-reducing antioxidant power (FRAP), inhibition of lipid peroxidation and iron chelation. In vivo, it was observed that mice treated with F1 and F2 showed amelioration of the inflammation by reducing UVB induced skin edema. However, only samples from animals treated with F1 had lower neutrophil recruitment (measured by myeloperoxidase activity), and returning the oxidative status to baseline levels in parameters such as reduced glutathione level, ferric reducing ability (FRAP), and scavenging of free radical (ABTS). Concluding, NE demonstrated a good antioxidant property in vitro, and the data suggest the use of NE added F1 to prevent skin damage caused by UVB irradiation.
\end{abstract}

Keywords: Antioxidant. Neem. Oxidative Stress. UVB Irradiation. Topical Formulation.

\section{How to cite}

Martinez RM, Souza CR, Melo CPB, Baracat MM, Arakawa NS, Duarte JC, Verri WA Jr, Casagrande R, Georgetti SR. Prevention of UVB radiation-induced oxidative stress in mice by topical administration of Azadirachta indica (neem) extract. Rev Ciênc Farm Básica Apl. 2020;41:e633. https://doi.org/10.4322/2179-443X.0633

\section{INTRODUCTION}

UVB radiation induces DNA damage by forming pyrimidine dimers, photoadducts, and DNA protein cross-links (Rastogi et al., 2010), leading to detrimental effects on biological systems. UVB exposure can also indirectly damage other cellular macromolecules such as proteins,

Financial support: Coordenação de Aperfeiçoamento de Pessoal de Nível Superior (CAPES), Conselho Nacional de Desenvolvimento Científico e Tecnológico (CNPq) and Fundação Araucária.

Conflicts of interest: The authors have no conflict of interest to declare.

Received on March 13, 2020. Accepted on May 28, 2020. 
lipids, and carbohydrates by generating reactive oxygen species (ROS) (Kim et al., 2015). It is well established that the inflammatory response that follows acute UV light irradiation of the skin and the degenerative process related to chronic UV exposure are largely mediated by the overproduction of ROS and free radicals, along with the impairment of antioxidant systems (Aquino et al., 2002).

Many efforts have been made in the search for strategies to avoid oxidative stress generated by sun exposure. Given the background, antioxidants from vegetable origin may represent new options for manage and avoid oxidative stress-mediated disorders. In recent years, various studies have been performed trying to establish and characterize natural antioxidants for topical application, including both isolated compounds and natural extracts (Marquele-Oliveira et al., 2007; Vicentini et al., 2008; Martinez et al., 2016b; Campanini et al., 2014).

Neem tree (Azadirachta indica A. Juss. fam. Meliaceae), a plant native from India and acclimated in most of tropical and subtropical countries, is of great medicinal value and largely distributed throughout the world. Its major chemical constituents include many biologically active components, for instance alkaloids, flavonoids, triterpenoids, phenolic compounds, carotenoids, steroids, ketones and volatile oils (El-hawary et al., 2013). Notably, trees from different tropical areas of the world are reported to contain a high level of polyphenolic compounds (Siddiqui et al., 1992; Sultana et al., 2007), but due to the ample dimension of geographical distribution, a large variety of morphological and biochemical characteristics have been reported, since phenolic contents of neem can be influenced by geographical locations and other abiotic factors (Ghimeray et al., 2009).

Preparations from the leaves of this plant have demonstrated well documented effects, such as antipyretic, hypoglycemic, antiulcer, antimalarial, antibacterial, antifungal, antiviral, antifertility (Biswas et al., 2002), and anticarcinogenic effects (Balasenthil et al., 1999). Additionally, neem oil is useful to treat skin infections (Biswas et al., 2002). Neem preparations in general are regarded as multi-functional, with the advantage of low toxicity, especially those preparations obtained from leaves, as already reported (Biswas et al., 2002; Balasenthil et al., 1999).

Thus, the employment of dermatologic formulations with $A$. indica might represent a promising approach for skin preservation against injuries generated by UV irradiation. The present study intended to perform a chemical characterization of $A$. indica ethanolic extract (neem tree), along with the in vitro determination of the extract's antioxidant capacity, and then the in vivo measurement of the effectiveness of formulations with the neem extract (NE) incorporated in the avoidance of oxidative skin injury, caused by UV in hairless mice.

\section{MATERIAL AND METHODS}

\subsection{Chemicals}

Quercetin (purity 99\%) was acquired from Acros Organics (Geel, Belgium). Folin Ciocalteau was purchased from Fluka Chemical Co. (São Paulo, Brazil). Reduced glutathione (GSH), hexadecyltrimethylammonium bromide (HTBA), 2,2' azino bis(3 ethylbenzothiazoline 6 sulfonic acid) (ABTS), (2,4,6 Tris(2 pyridyl)s triazine) (TPTZ), 5,5'dithio-bis-(2-nitrobenzoic acid) (DTNB), Azarachtin (purity 95\%), rutin (purity $\geq 94 \%$ ), ursolic acid (purity $\geq 90 \%$ ), tannic acid (purity 95\%), Trolox and acid galic were supplied by from Sigma Chemical Co. (São Paulo, Brazil). Materials for formulations were obtained from Galena (Campinas, Brazil). All other reagents utilized were of pharmaceutical grade.

\subsection{Plant material and preparation of the extract}

Leaves of Neem tree (Azadirachta indica A. Juss. fam. Meliaceae) were collected from Instituto Agronômico do Paraná (IAPAR) (Latitud-23 21' 28.96" South, Longitude- 51 9' 42.84" West), Londrina-Paraná, Brazil, by the Prof. Dr. José Carlos Duarte in November, 2010. 
The plant material was authenticated by Dra. Ana Odete Santos Vieira and a voucher specimen was deposited at the Herbarium of Universidade Estadual de Londrina under code No. FUEL 48154. Neem leaves were dried in a forced air drying oven and milled, using a knife mill to pass through a $1 \mathrm{~mm}$ screen. The extract was prepared by ethanolic extraction, $(1: 10 \mathrm{w} / \mathrm{v})$ kept for 3 days on a shaker at ambient temperature, and then filtered under vacuum.

\subsection{Chemical characteristics of neem extract (NE)}

\subsubsection{Total flavonoids and polyphenol contents}

The Folin Ciocalteau colorimetric method was applied to analyze the total polyphenol content of NE (Kumazawa et al., 2004). Therefore, $0.5 \mathrm{~mL}$ of NE was blended with $0.5 \mathrm{~mL}$ of the Folin Ciocalteau testing agent and $0.5 \mathrm{~mL}$ of $10 \% \mathrm{Na}_{2} \mathrm{CO}_{3}$, and then $1 \mathrm{~h}$ of incubation at room temperature (RT) the absorbance was determined at $760 \mathrm{~nm}$ (Evolution 60, Thermo Scientific). Total polyphenol content was represented as milligrams per gram (gallic acid equivalents). The aluminum chloride colorimetric method was employed to determinate the total flavonoid composts of NE. To $0.5 \mathrm{~mL}$ of $\mathrm{NE}, 0.5 \mathrm{~mL}$ of $2 \% \mathrm{AlCl}_{3}$ ethanolic solution was included. After $1 \mathrm{~h}$ at RT, the absorbance was analyzed at $420 \mathrm{~nm}$. Total flavonoid contents were estimated as quercetin ( $\mathrm{mg} / \mathrm{g}$ ) from an analytical curve (Kumazawa et al., 2004).

\subsubsection{HPLC}

The high-performance liquid chromatography (HPLC; Shimadzu) was employed to evaluate the $A$. indica extract. The equipment utilized was equipped with a photodiode array detector (SPD M10Avp), multisolvent delivery system (LC 10Avp), oven control system (CTO 10ASvp), and controlled software Class VP 6.14 software. Chromatography was operated using an analytical reverse-phase column Spherisob ${ }^{\circledR}$ (C 18ODS) (250×4.6mm i.d.; particule size $5 \mu \mathrm{m}$; Waters). The HPLC-grade reagents were obtained from Panreac ${ }^{\circledR}$, and water was purified using Milli-Q-plus filter systems (Millipore). The chromatographic conditions were settled as: a gradient of acidified $\mathrm{H}_{2} \mathrm{O}$ ( $2 \%$ formic acid; solvent $\mathrm{A}$ ) and acetonitrile ( $2 \%$ formic acid; solvent $B$ ) was used at a flow rate of $1 \mathrm{~mL} / \mathrm{min}$, and the volume injected was $20 \mu \mathrm{L}$ ( 0 min, 0\% B; 5 min, 0\% B; 20 min, 2.5\% B; 30 min, 5\% B; 50 min, 15\% B; 60 min, 25\% B; 65 min, 30\% B; $70 \mathrm{~min}, 45 \% \mathrm{~B} ; 75 \mathrm{~min}, 50 \% \mathrm{~B}$; 80min, 70\% B; $85 \mathrm{~min}, 90 \% \mathrm{~B} ; 90 \mathrm{~min}, 100 \% \mathrm{~B} ; 95 \mathrm{~min}, 100 \% \mathrm{~B}$; $110 \mathrm{~min}, 0 \% \mathrm{~B}$ ). For every main peak in the chromatograms, UV spectra were registered (Campanini et al., 2014). The following compounds were employed as references: Azadirachtin (A), rutin (B), ursolic acid (C) and tannic acid (D).

\subsection{Determination of in vitro antioxidant efficacy of NE}

\subsubsection{Scavenging ability of NE using ABTS method}

The method was carried out as reported by Sánchez Gonzalez et al. (2005) with few adjustments. After the reaction of ABTS $7 \mathrm{mM}$ stock solution with $2.45 \mathrm{mM}$ of potassium persulfate, the radical cation ABTS was achieved. This solution was diluted in phosphate buffer $(\mathrm{pH} 7.4,0.1 \mathrm{M})$ to obtain an absorbance of 0.7 at $730 \mathrm{~nm} .50 \mu \mathrm{L}$ of Neem samples were combined with $4 \mathrm{~mL}$ of the diluted ABTS solution. The concentrations of NE obtained in the reaction medium were 0.7 to $12.5 \mu \mathrm{L} / \mathrm{mL}$. After 6 minutes of incubation at RT, the absorbance was determined in a spectrophotometer at 730nm (Sánchez-González et al., 2005). Samples were prepared and appraised in triplicate and the ABTS radical scavenging ability was determined by the following equation: Equation $\mathrm{I}$ : \% of activity $=[1-$ (sample absorbance/control absorbance)] $\times 100$. 


\subsubsection{Evaluation of the Ferric Reducing Antioxidant Power (FRAP) of NE}

NE ferric reduction antioxidant power analysis was executed as reported by Sánchez Gonzalez et al. (2005) with few adjustments.

FRAP reagent was prepared with $2.5 \mathrm{~mL}$ of a solution of TPTZ $(10 \mathrm{mM})$ in $\mathrm{HCl}(40 \mathrm{mM})$, $2.5 \mathrm{~mL} \mathrm{FeCl}\left(6 \mathrm{H}_{2} \mathrm{O}\right)$ solution and $25 \mathrm{~mL}$ of acetate buffer $(\mathrm{pH} 3.6,0.3 \mathrm{mM})$. The solution was incubated at $37^{\circ} \mathrm{C}$ for 30 minutes. For the assay, $900 \mu \mathrm{L}$ of FRAP reagent were added to $90 \mu \mathrm{L}$ of water and $10 \mu \mathrm{L}$ of trolox standard or $10 \mu \mathrm{L}$ of $\mathrm{NE}(50 \mu \mathrm{L} / \mathrm{mL}$ in the reaction medium). The analysis was executed in a spectrophotometer at $595 \mathrm{~nm}$, after 30 minutes of incubation at $37^{\circ} \mathrm{C}$.

An analytical curve with different concentrations of trolox $(4.0-20.0 \mu \mathrm{M})$ was employed for subsequent determination of results in $\mu \mathrm{mol} / \mathrm{L}$ trolox equivalent $/ \mu \mathrm{L} / \mathrm{mL}$ of extract. A positive control was operated using ethanol (Sánchez-González et al., 2005).

\subsubsection{Iron-induced lipid peroxidation}

The ability of the $N E$ to inhibit in vitro lipid peroxidation was evaluated by diminish in the malondialdehide (MDA) formation, which is a secondary product of lipid peroxidation. Samples of NE ( 0.094 to $6.0 \mu \mathrm{L} / \mathrm{mL}$ in the reaction medium) were added to reaction medium containing $1 \mathrm{~mL}$ of reaction medium $(\mathrm{KCl} 130 \mathrm{mM}$ and tris $-\mathrm{HCl} 10 \mathrm{mM}$, $\mathrm{pH}$ 7.4) and $2 \mathrm{mM}$ sodium citrate, mitochondria (1 mg of protein) and amonical ferrous sulphate $50 \mu \mathrm{M}$. Reaction was incubated at $37^{\circ} \mathrm{C}$ for $30 \mathrm{~min}$. After, MDA formation was determined using $1 \mathrm{~mL}$ of thiobarbituric acid (TBA) $1 \%$ prepared in $\mathrm{NaOH} 50 \mathrm{mM}, 0.1 \mathrm{~mL}$ of $\mathrm{NaOH} 10 \mathrm{M}$ and $0.5 \mathrm{~mL}$ of $\mathrm{H}_{3} \mathrm{PO}_{4} 20 \%$ followed by incubation for $20 \mathrm{~min}$ at $85{ }^{\circ} \mathrm{C}$. The MDA-TBA complex was extracted with $2 \mathrm{~mL}$ of $\mathrm{n}$-butanol, centrifuged at $3000 \times \mathrm{g}$ for $15 \mathrm{~min}$ and the absorbance determined at $535 \mathrm{~nm}$. The mitochondria were obtained from hairless mice and their isolation was performed by differential centrifugation. The mitochondrial protein content was determined by the biuret reaction. All analysis were made in triplicate. The inhibition of iron-dependent lipoperoxidation was determined by equation I (Casagrande et al., 2006).

\subsubsection{Determination of iron-chelating activity of NE using the bathophenanthroline (BPS) assay}

BPS is a strong chelator of ferrous ion and this reaction results in a colored complex. $\mathrm{NE}$ ( 0.50 to $10 \mu \mathrm{L}$ in the reaction medium) chelating activity of iron was monitored through the elimination of the $\mathrm{Fe}_{2}(\mathrm{BPS})_{3}$ complex formation. Measurements were performed at 530 and $700 \mathrm{~nm}$. All measurements were made in triplicate (Casagrande et al., 2006).

\subsection{Formulations}

Both formulations (F1 and F2) were prepared by the same method, but with different lipid content (Table 1). In addition, the self-emulsifying wax Polawax® was also utilized in the two formulations, but at variated concentrations (10\% in F1 and $2 \%$ in F2), and in F2 the stabilizing agent Aristoflex $\operatorname{AVC}^{\circledR}(20 \%$ of solution at $5 \%)$ was added. Caprylic/capric triglyceride (5\%) was used as the emollient and propylene glycol (5\%) as humectant. A mixture of parabens was used as preservative and deionized water was utilized for the preparation of the formulations. NE was incorporated $(10 \%)$ into the formulations at room temperature. All concentrations of the formulations raw materials were described as percentages weight/weight. Control formulations did not contain extract. 
Table 1. Percent composition (weight/weight) of F1 and F2

\begin{tabular}{lcc}
\hline Components & F1 & F2 \\
\hline Polawax $^{\circledR a}$ & 10.0 & 2.0 \\
Caprylic/ capric triglyceride $^{\boldsymbol{b}}$ & 5.0 & 5.0 \\
Aristoflex AVC $^{\circledR}(5 \%)^{\boldsymbol{b}}$ & - & 20.0 \\
Propylene glycol $_{\text {Triethanolamine }}$ & 5.0 & 5.0 \\
Solution of methyl (10\%) and propylparaben (2\%) & - & 0.2 \\
Deionized water (qsp)* $^{*}$ & 1.0 & 1.0 \\
\hline
\end{tabular}

* Quantity sufficient for preparation; ${ }^{a}$ Self-emulsifying wax (Cetostearyl alcohol and polyoxyethylene derived from a fatty acid ester of sorbitan $20 \mathrm{0E}) ;{ }^{b}$ Ammonium Acryloyldimethyltaurate/VP Copolymer

\subsection{Assessments of formulation containing NE against UVB-induced skin damage} in vivo

\subsubsection{Animals and experimental protocol}

In vivo experiments were executed in sex matched hairless mice (HRS/J), weighing 20 to $30 \mathrm{~g}$, obtained from University Hospital of Londrina State University. Mice were accommodated in cages, in a $23 \pm 2^{\circ} \mathrm{C}$ temperature controlled room, with free access to water and food and maintained under $12 \mathrm{~h}$ light and $12 \mathrm{~h}$ dark cycles. All procedures were operated with the consent of the Animal Ethics Committee (O. Circ. CEEA No. 164/2013 in September 04, 2013, process No. 7074.2012.88) and all efforts were made to reduce the number of animals involved, as well as their suffering. The animals were casually assigned to groups with 5 mice each as follows: non-irradiated control, irradiated control, irradiated and treated with $\mathrm{F} 1$ without $\mathrm{NE}$, irradiated and treated with $\mathrm{F} 1$ added with $\mathrm{NE}$, irradiated and treated with $\mathrm{F} 2$ without NE, and irradiated and treated with F2 added with NE. Mice received topical treatment on the posterior surface with $0.5 \mathrm{~g}$ of the formulation, $12 \mathrm{~h}, 6 \mathrm{~h}$, and $5 \mathrm{~min}$ before the irradiation and finally right after irradiation.

\subsubsection{Irradiation}

The UVB source of irradiation consisted of a Philips TL40W/12 RS lamp (Medical-Holand) emitting a constant spectrum between 270 and $400 \mathrm{~nm}$ with a peak emission at $313 \mathrm{~nm}$. The lamp was mounted $20 \mathrm{~cm}$ overhead the table where the mice were allocated on, resulting in an irradiation of $0.384 \mathrm{~mW} / \mathrm{cm}^{2}$, as determinate by an IL 1700 radiometer (Newburyport, MA, USA) with sensor for UV (SED005) and UVB (SED240). The dose of UVB employed was $4.14 \mathrm{~J} / \mathrm{cm}^{2}$ (Martinez et al., 2017), (Campanini et al., 2013). After $12 \mathrm{~h}$ UVB exposure, the mice were euthanized by $1.5 \%$ isoflurane, and the full thickness of the dorsal skins were extracted and placed at $-80^{\circ} \mathrm{C}$ for further analysis. For the measurement of cutaneous edema, the samples collected were weighed immediately after the extraction and were not frozen.

\subsubsection{Edema evaluation}

By measuring the increment in the dorsal skin weight, the skin edema was evaluated. After removal of the dorsal skin, using a mold, a constant area was determined, and successively the weighing was performed. The result is expressed in mg of skin (Campanini et al., 2013).

\subsubsection{Myeloperoxidase (MPO) activity}

MPO colorimetric assay was employed to analyze the UVB induced neutrophils migration to skin, as reported formerly (Martinez et al., 2015). Samples of posterior skin were homogenized in $\mathrm{K}_{2} \mathrm{HPO}_{4}$ buffer $0.05 \mathrm{M}(\mathrm{pH} 6.0)$ containing $0.5 \% \mathrm{HTAB}$ using a Tissue-Tearor (Biospec). The homogenates were centrifuged at $16.100 \mathrm{~g}$ for $2 \mathrm{~min}$ at $4^{\circ} \mathrm{C}$, and $30 \mu \mathrm{L}$ of the resulting supernatant were mixed with $200 \mu \mathrm{L}$ of $0.05 \mathrm{M} \mathrm{K}_{2} \mathrm{HPO}_{4}$ buffer $(\mathrm{pH} 6.0)$, containing 
$0.0167 \%$ o-dianisidine dihydrochloride and $0.05 \%$ hydrogen peroxide. The absorbance was measured at $450 \mathrm{~nm}$. MPO activity of samples was compared to a standard curve of neutrophils. The findings were described as number of neutrophils per mg of skin.

\subsubsection{Reduced glutathione (GSH) assay}

GSH was determined as described previously (Martinez et al., 2016a). Briefly, skin samples were homogenized in $0.02 \mathrm{M}$ EDTA using a Tissue-Tearor (Biospec). Whole homogenates were treated with $50 \%$ trichloroacetic acid and were centrifuged twice at $2700 \mathrm{~g}$ for $10 \mathrm{~min}$ at $4{ }^{\circ} \mathrm{C}$. The reaction mixture contained $50 \mu \mathrm{L}$ of sample, $100 \mu \mathrm{L}$ of $0.4 \mathrm{M}$ Tris, and $5 \mu \mathrm{L}$ of DTNB $(1.9 \mathrm{mg} / \mathrm{mL}$ in methanol). The color developed was read at $405 \mathrm{~nm}$. The standard curve was prepared with 5-150 $\mu \mathrm{M}$ of GSH. The results are presented as $\mu \mathrm{M}$ of GSH per milligram of skin.

\subsubsection{FRAP and ABTS assay}

The FRAP assay was utilized to measure the reducing ability of the skin. Formerly, a curve of trolox $(0.5$ to $20 \mu \mathrm{M})$ was prepared and the findings were demonstrated as $\mu \mathrm{M}$ trolox equivalent per mg of skin. The ABTS radical scavenging potential of the skin was calculated by the decline of absorbance at $730 \mathrm{~nm}$. Previously, a curve of trolox (1 to $25 \mu \mathrm{M}$ ) was realized and the findings were demonstrated as $\mu \mathrm{M}$ trolox equivalent per mg of skin (Martinez et al., 2015).

\subsection{Statistical analysis}

The GraphPad Prism ${ }^{\circledR} 7$ software was employed to analyze the presented results, and they were expressed as mean \pm standard error mean (SEM). The data originated from the in vitro analysis were obtained from two distinct experiments, comprising triplicates for each one. The concentration of NE necessary to suppress the oxidative process by $50 \%\left(\mathrm{IC}_{50}\right)$ was established utilizing hyperbolic curve. In vivo findings are demonstrated as mean \pm SEM of 5 mice per group per experiment and are representative of two distinct procedures. The differences were analyzed by ANOVA followed by Tukey's test. Statistical differences were considered significant at $p<0.05$.

\section{RESULTS}

Findings demonstrated that NE presented $135.3 \pm 0.09 \mathrm{mg} / \mathrm{g}$ and $37.12 \pm 0.05 \mathrm{mg} / \mathrm{g}$ of polyphenols and flavonoids, respectively. Reference compounds azarachtin, rutin, ursolic acid and tannic acid were identified in the ethanolic extract (Figure 1). Identification of main biological compounds was carried out by HPLC-UV-DAD (Liquid Chromatography with PhotoDiode Array Detection $\lambda \max$ ) and compared with commercial standards (Sigma-Aldrich).

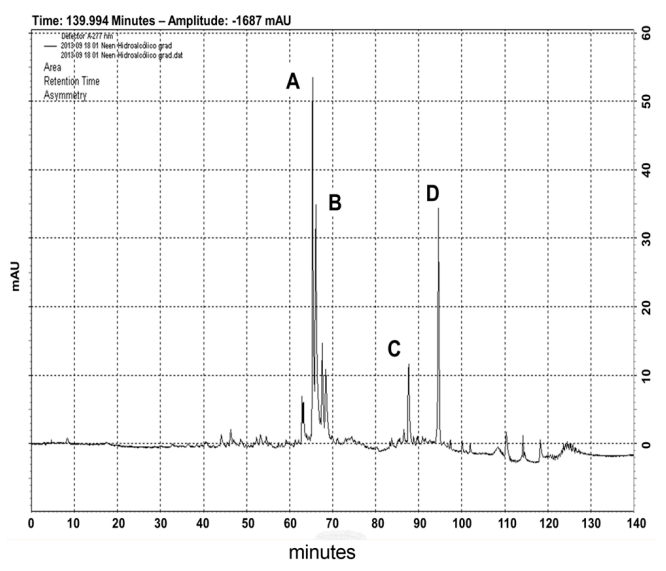

Figure 1. Identification of main components of Azadirachta indica ethanolic extract using high-performance liquid chromatography. Azadirachtin (A), rutin (B), ursolic acid (C) and tannic acid (D). 
NE demonstrated ABTS radical scavenging capacity (Figure $2 \mathrm{~A}$ ), inhibition of lipid peroxidation (Figure $2 \mathrm{~B}$ ) and iron chelating activity (Figure $2 \mathrm{C}$ ) with $\mathrm{IC}_{50}$ of $3.82 \mu \mathrm{L} / \mathrm{mL}, 1.165 \mu \mathrm{L} / \mathrm{mL}$ and $2.324 \mu \mathrm{L} / \mathrm{mL}$, respectively. For quercetin control, the values found were $\mathrm{IC}_{50}$ of $0.82 \mu \mathrm{g} / \mathrm{mL}$, $0.34 \mu \mathrm{g} / \mathrm{mL}$ and $4 \mu \mathrm{g} / \mathrm{mL}$ for ABTS assay, lipid peroxidation and iron chelation assays, respectively. Ferric reducing antioxidant power of $\mathrm{NE}$, as evaluated by FRAP assay, was $0.265 \mu \mathrm{mol} / \mathrm{L}$ trolox equivalent $/ \mu \mathrm{L} / \mathrm{mL}$ of extract.
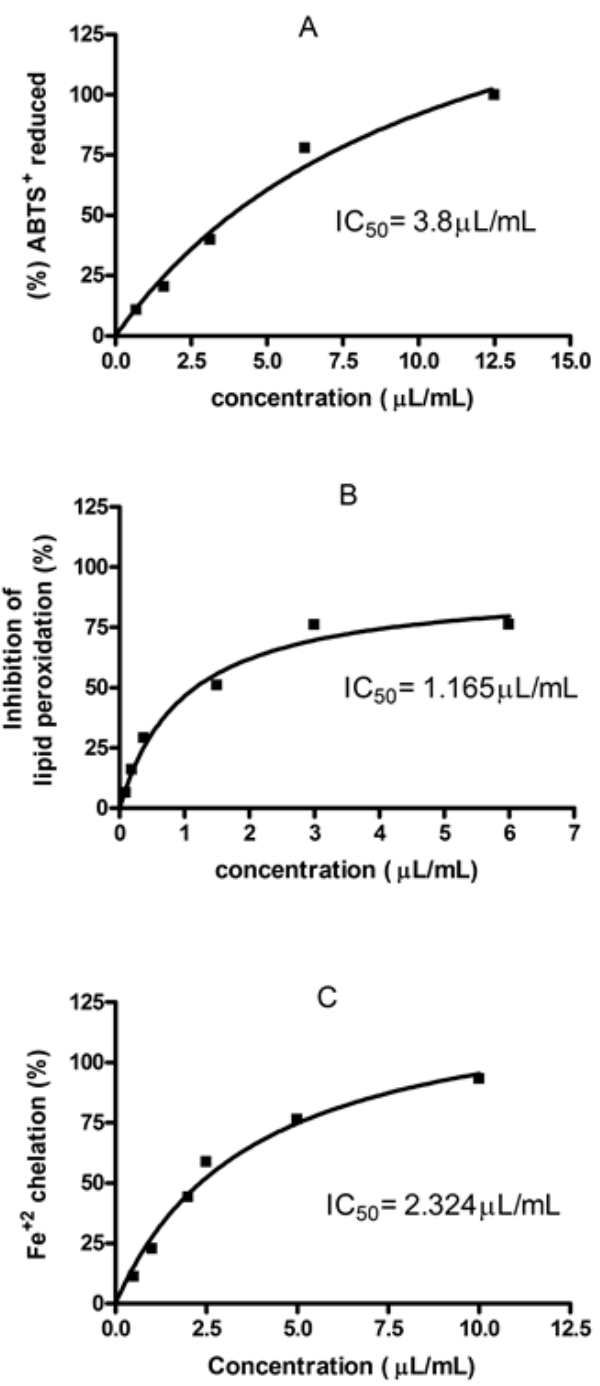

Figure 2. Scavenging ability of neem extract using ABTS method (concentrations of neem on the reaction medium, $0.7-12.5 \mu \mathrm{L} / \mathrm{mL}$ ) (A). Inhibition by neem extract of lipid peroxidation induced by $\mathrm{Fe}^{2+/} \mathrm{citrate}$ (concentrations of neem on the reaction medium, $0.094-6.0 \mu \mathrm{L} / \mathrm{mL}$ ) (B) and chelating activity of $\mathrm{Fe}^{2+}$ ions by neem extract (concentrations of neem on the reaction medium, 0.50-10 $\mu \mathrm{L} / \mathrm{mL}$ ) (C). Results are represented by means \pm SEM of three separated experiments.

Several studies have shown that exposure to UVB light leads to skin edema, which can be considered a marker of skin inflammation (Afaq et al., 2005b; Bhatia et al., 2011). As shown in Figure 3, UVB exposure increased punch weight approximately 1.5 fold in comparison with untreated irradiated animals and irradiated animals treated with control formulations. F1 and F2 containing NE were able to minimize edema formation, lowering punch weight values to control levels. 


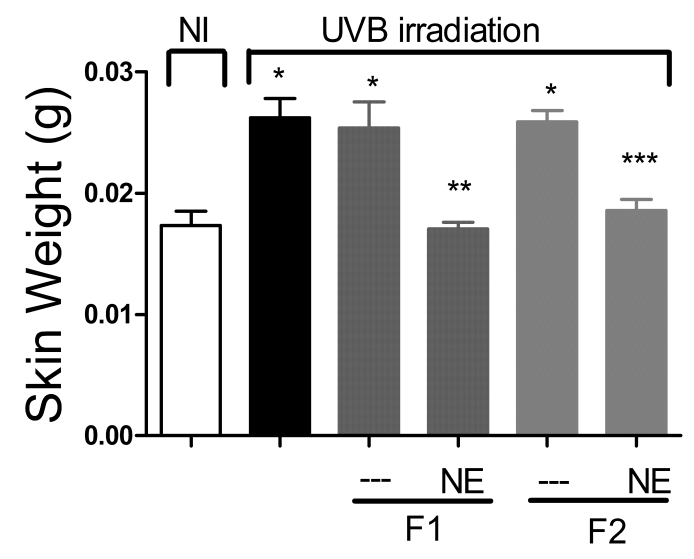

Figure 3. Effect of formulations containing neem extract on UVB irradiation-induced edema. The skin edema was determined $12 \mathrm{~h}$ after the end of irradiation. Bars represent means \pm SEM of 2 separated experiments, 5 mice per group. ${ }^{*} p<0.05$ compared to the control (non-irradiated) group, ${ }^{* *} p<0.05$ compared to irradiated group and formulation 1 (F1) control group, and $* * * p<0.05$ compared to irradiated group and formulation 2 (F2) control group. Non-irradiated group (NI), neem extract (NE).

The results showed that the UVB radiation induced an increase of approximately 8.3 fold in the MPO activity in skin samples from untreated irradiated animals and from irradiated animals treated with control formulations. F1 containing NE inhibited MPO activity induced by UVB to the level of non-irradiated control (Figure 4), while F2 did not influence significantly the reduction in neutrophils recruitment. It is also important to notice that UVB irradiation leads to an imbalance between ROS and the endogenous antioxidants, causing the elevation of the first and the depletion of the last (Valko et al., 2007).

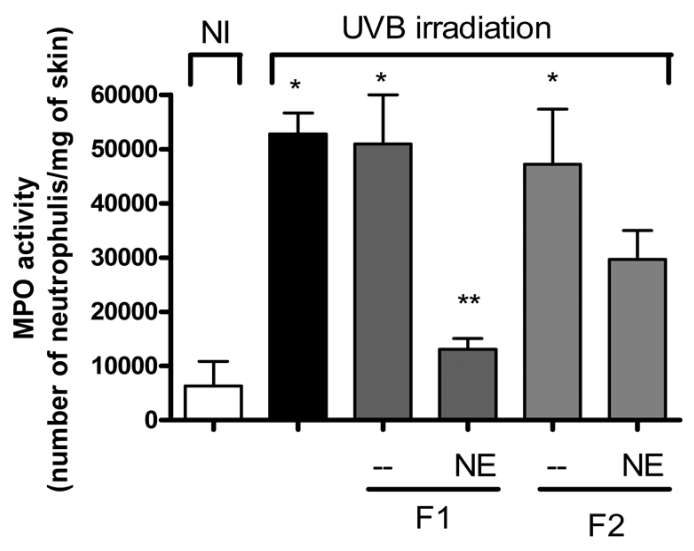

Figure 4. Effect of formulations containing neem extract on UVB irradiation-induced MPO activity. The MPO activity was determined $12 \mathrm{~h}$ after the end of irradiation. Bars represent means \pm SEM of 2 separated experiments, 5 mice per group. ${ }^{*} p<0.05$ compared to the control (non-irradiated) group, and ${ }^{*} \mathrm{p}<0.05$ compared to irradiated group and formulation 1 (F1) control group. Non-irradiated group (NI), neem extract (NE).

The dosage of UVB irradiation employed in the experiment was able to significantly reduce approximately 2.67 fold the endogenous antioxidant GSH in skin samples from the irradiated group control compared with samples from non irradiated control. The findings demonstrated that only F1 added with NE was able to inhibit depletion of endogenous antioxidant GSH, and maintain levels similar to those found in the non irradiated control group (Figure 5A). UVB radiation also reduced the antioxidant capacity of the skin of irradiated mice compared with non irradiated control, as demonstrated by the FRAP and ABTS tests 
(Figure 5B and 5C, respectively). However, animals treated with F1 formulation containing NE presented levels comparable to those found in non irradiated control in both tests. F2 added with NE was not effective in inhibiting significantly the reduction of antioxidant capacity due to exposure of the skin to UVB radiation.

A

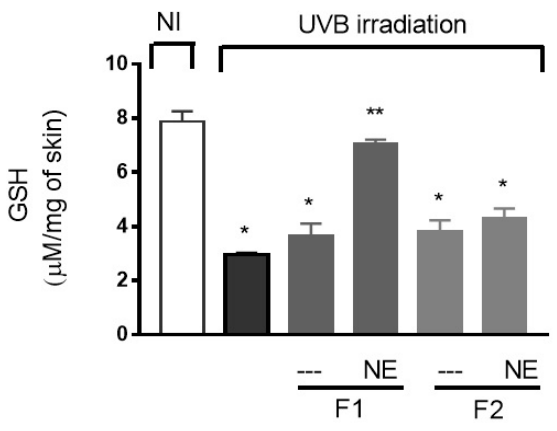

B

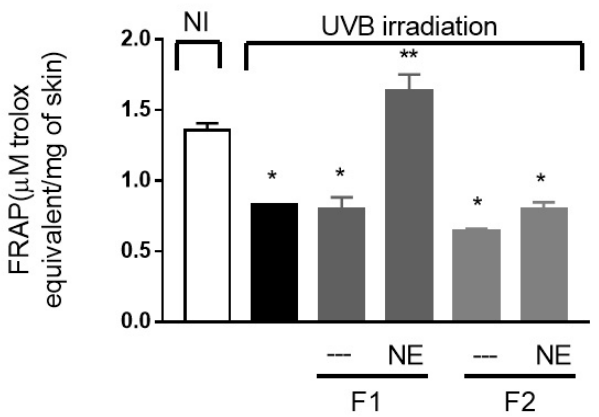

C

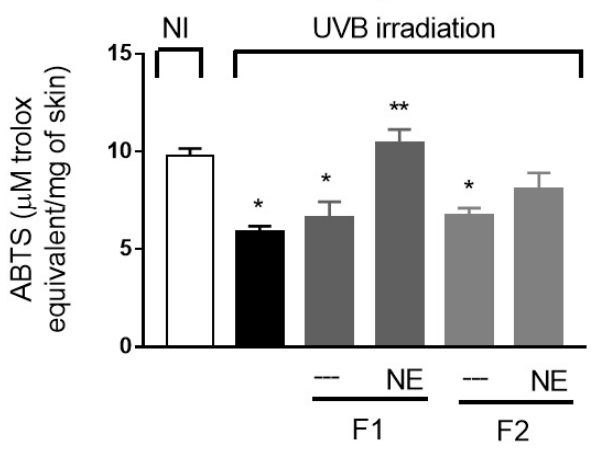

Figure 5. Effect of formulations containing neem extract on UVB irradiation-induced GSH (A) depletion and the antioxidant capacity of skin by ferric reducing antioxidant power (FRAP) (B) and ABTS assay (C). The antioxidant activity was determined $12 \mathrm{~h}$ after the end of irradiation. Bars represent means \pm SEM

of 2 separated experiments, 5 mice per group. ${ }^{*} p<0.05$ compared to the control (non-irradiated) group, and ${ }^{*} \mathrm{p}<0.05$ compared to irradiated group and F1 control group. Non-irradiated group (NI), neem extract (NE).

\section{DISCUSSION}

Recently, extracts from antioxidant rich plants achieved attention from studies throughout the world, due to the possibility of been used as a treatment and prevention of oxidative stress-mediated disorders (Marquele-Oliveira et al., 2007).

The plant Azadirachta indica, also known as Neem, is an antique specie recognized for its extensive range of biological activities. Diverse parts of the tree, such as bark, seed, leaf, fruit, gum, and oil, contain compounds that are regarded as responsible for remarkable therapeutic 
applications, including antiviral, antibacterial, antitumor, antimicrobial, antipyretic, analgesic, antifungal, anti-inflammatory and immunostimulant (El-hawary et al., 2013; Siddiqui et al., 1992; Sultana et al., 2007; Ghimeray et al., 2009; Biswas et al., 2002).

In this study, findings demonstrated that the polyphenol content of the NE was approximately 3.65 times superior to the total flavonoid content, validating other studies that show that $A$. indica contains not only flavonoids, but also a variety of other polyphenolic substances, like tannins, coumarins, and dihydrichalconas (van der Nat et al., 1991). In addition, NE obtained in this study showed higher content of polyphenols and flavonoids than those found by Ghimeray et al. (Ghimeray et al., 2009) (ranging from 23.85 to $237.00 \mu \mathrm{g} / \mathrm{mg}$ and 13.72 to $93.17 \mu \mathrm{g} / \mathrm{mg}$, respectively). This difference can be elucidated by the fact that, as it has been well reported, phenolic contents of neem can be influenced by the geographical location of the trees, likewise by several abiotic factors (Kaura et al., 1998). This information is relevant since it has been also reported that divergences in the levels of phenolic substances provoke fluctuations in the antioxidant activity of the plant (Biswas et al., 2002).

Chemical investigation on the products of neem tree was extensively undertaken in the middle of the twentieth century. More than 135 compounds have been isolated from different parts of the tree and several reviews have also been published on the chemistry and structural diversity of these compounds (Koul et al., 1990; Champagne et al., 1992). In this study, azadirachtin, rutin, ursolic acid and tannic acid were identified in the extract as major compounds. It is possible that these substances may exert synergistic antioxidant effect.

It is important to consider that oxidative stress is related with the kind of generated ROS, also with the location and the manner how ROS are generated, and on the oxidative target as well. In view of this, the antioxidant capacity of NE was measured by four different methods in vitro, and demonstrated in all four methods a relevant and dose dependent antioxidant activity, as indicated by the values of $\mathrm{IC}_{50}$. NE demonstrated ABTS radical scavenging capacity, inhibition of lipid peroxidation and iron chelating activity with $\mathrm{IC}_{50}$ of $3.82 \mu \mathrm{L} / \mathrm{mL}, 1.165 \mu \mathrm{L} / \mathrm{mL}$ and $2.324 \mu \mathrm{L} / \mathrm{mL}$, respectively. Tephrosia sinapou extract presented radical scavenging capacity, and inhibition of lipid peroxidation with $\mathrm{IC}_{50}$ of $54.51 \mu \mathrm{L} / \mathrm{mL}$ and $20.10 \mu \mathrm{L} / \mathrm{mL}$, respectively (Martinez et al., 2012). Moreover, Beta vulgaris dye enriched in betalains, extract with prominent anti-inflammatory and antioxidant effects, showed ABTS scavenging capacity, inhibition of lipid peroxidation and iron chelating activity with $\mathrm{IC}_{50}$ of $41.14 \mu \mathrm{L} / \mathrm{mL}, 491.90$ $\mu \mathrm{L} / \mathrm{mL}$ and $38.88 \mu \mathrm{L} / \mathrm{mL}$, respectively (Martinez et al., 2020). These studies corroborates the relevance of free radical scavenging activity of $\mathrm{NE}$, since values of $\mathrm{IC}_{50}$ were lower than others extracts, what may suggest the effectiveness in vivo of NE.

The findings indicate that the antioxidant properties of the extract depend on a combination of activities, such as sequestration of free radicals and chelation of transition metals, which will prevent the formation of radicals and, consequently, lipid peroxidation. It is notable that the antioxidant method can evaluate the activity of the whole extract, since the components present in the extract might be acting in a synergic form. Moreover, considering the difficulty of employment specific markers, due to the extract chemical constitution variation according to the collecting area, the antioxidant evaluation might be a useful alternative (Marquele-Oliveira et al., 2007; Park et al., 2002).

Antioxidants from vegetal sources are presented as alternatives to manage and avoid oxidative and stress-mediated disorders, among them those originated in the skin (Afaq \& Mukhtar, 2006). As the skin is the main barrier to solar radiation, it is deeply affected by the harmful effects of solar radiation, which UVB rays being of major importance (Ichihashi et al., 2003). The two fundamental consequences of exposition to UVB are the development of inflammatory process mediated by an overproduction of ROS, and the depletion of endogenous antioxidant. Furthermore, the accumulation of injuries from prolonged exposure to UVB was shown to be a cause of skin cancer and premature skin aging (Afaq et al., 2005a).

Therefore, in recent years, many researches have been trying to establish and characterize natural antioxidants for topical application. Studies have been carried out, not only with 
isolated compounds, such as quercetin (Vicentini et al., 2008), genistein and daidzein (Huang et al., 2008), but also with plant extracts, such as Glycyrrhiza glaba and Ginkgo biloba (Di Mambro \& Fonseca, 2005).

The spectrum of UV light that induces edema in hairless mice and erythema in humans is the same. Because of this similarity, a change in sensitivity to UV radiation in mice, as evaluated by skin edema, should reliably predict this change in humans (Campanini et al., 2013). Our results clearly show that NE incorporated to both formulations was able to inhibit skin edema in animals exposed to UV irradiation. Supporting the present data, it has been already demonstrated that the ethanolic extract of $A$. indica inhibited carrageenan induced rat paw edema (Sonika et al., 2010), suggesting that NE has applicability in inflammation models with different triggering mechanisms. Indeed, studies show that other plants with antioxidant activity in vitro have in vivo anti-inflammatory activity screened by different mechanisms (Martinez et al., 2012, 2020; Campanini et al., 2014).

MPO plays an important function in the defense of the innate immune system and can be employed as a marker of the existence of neutrophils or inflammation (Jantschko et al., 2005). One of the special products from neutrophils is the heme enzyme MPO, which is stored in large amounts in the azurophilic granules of these cells. MPO derived hypochlorous acid $(\mathrm{HOCl})$ reacts with proteins, DNA, and lipids to form long lived oxidants, which have been implicated in processes like carcinogenesis, atherosclerosis, and chronic renal failure (WitkoSarsat et al., 2000). Treatment with F1 containing NE significantly reduced UVB irradiation induced infiltration of leukocytes into the skin of treated hairless mice, thus demonstrating its anti-inflammatory and protective activity. In agreement, $A$. indica leaves extract reduced the MPO activity in acetic acid (Gautam et al., 2013) and trinitrobenzene sulfonic acid-induced colitis in rats (Moneim et al., 2014).

GSH is an epidermal marker sensitive to UVB generated oxidative stress (Valko et al., 2007). GSH is the primary internal redox regulator during oxidative stress occurrence and a wellknown antioxidant; therefore, any change in GSH levels indicates an imbalance of the internal redox (Campanini et al., 2013).

The redox status of glutathione has been confirmed as an early and sensitive sensor of UVB induced epidermal oxidative stress, suitable for testing the protective antioxidant effects of a substance (Martinez et al., 2017). Topical treatment with F1 added with NE maintained GSH levels close to non irradiated control, thus demonstrating that this formulation significantly prevented UVB irradiation induced depletion of GSH. A. indica provided a significant protective effect against cisplatin induced renal oxidative stress by measuring GSH levels (Moneim et al., 2014). Additionally, F1 was the only treatment which demonstrated improvement at the antioxidant capacity of the skin, demonstrated by FRAP and ABTS assays. ABTS assay has been found to correspond efficiently with endogenous glutathione levels, whilst FRAP assay precisely reproduced plasma levels of ascorbic acid, uric acid and a-tocopherol (Katalinic et al., 2005).

Active molecules in extracts present varied chemical and physical characteristics to be considered in the development of pharmaceutical formulations. Moreover, semi-solid emulsions are used as vehicles to pharmaceutical formulations for skin release and their coloidal properties influence drug bioavailability (Campanini et al., 2014). Thus, it is important to use formulations with different proportions of lipidic to determine the effectiveness in vivo. The excipients and concentrations used in formulations F1 and F2 were chosen based on the previous studies of our group. Release may be improved by selecting the appropriate vehicle. Herein, it was found that the formulation with higher lipid content was effective in all parameters, while the one with less lipid content is effective only in the reduction of edema formation, thus the difference in lipid content may affect the release of active components of the NE, and consecutively the effectiveness in vivo.

Therefore, the present data demonstrated that there is a beneficial effect of NE against UVB-induced skin oxidative stress and also that the type of formulation used can influence the antioxidant efficiency of the extract. Thus, the data suggest the use of NE added 
formulation with higher lipid content to prevent skin damage caused by UVB irradiation and demonstrates the importance of conducting further pre-clinical and clinical studies with this extract.

\section{ACKNOWLEDGEMENTS}

This study was supported by grants from Coordenação de Aperfeiçoamento de Pessoal de Nível Superior (CAPES), Conselho Nacional de Desenvolvimento Científico e Tecnológico (CNPq) and Fundação Araucária.

\section{REFERENCES}

Afaq F, Adhami VM, Mukhtar H. Photochemoprevention of ultraviolet B signaling and photocarcinogenesis. Mutat Res. 2005a;571(1-2):153-73. http://dx.doi.org/10.1016/j.mrfmmm.2004.07.019. PMid:15748645.

Afaq F, Mukhtar H. Botanical antioxidants in the prevention of photocarcinogenesis and photoaging. Exp Dermatol. 2006;15(5):678-84. http://dx.doi.org/10.1111/j.1600-0625.2006.00466.x. PMid:16881964.

Afaq F, Saleem M, Krueger CG, Reed JD, Mukhtar H. Anthocyanin- and hydrolyzable tannin-rich pomegranate fruit extract modulates MAPK and NF-kappaB pathways and inhibits skin tumorigenesis in CD-1 mice. Int J Cancer. 2005b;113(3):423-33. http://dx.doi.org/10.1002/ijc.20587. PMid:15455341.

Aquino R, Morelli S, Tomaino A, Pellegrino M, Saija A, Grumetto L, Puglia C, Ventura D, Bonina F. Antioxidant and photoprotective activity of a crude extract of Culcitium reflexum H. B. K. leaves and their major flavonoids. J Ethnopharmacol. 2002;79(2):183-91. http://dx.doi.org/10.1016/S03788741(01)00379-8. PMid:11801380.

Balasenthil S, Arivazhagan S, Ramachandran CR, Ramachandran V, Nagini S. Chemopreventive potential of neem (Azadirachta indica) on 7, 12-dimethylbenz [ a ] anthracene (DMBA) induced hamster buccal pouch carcinogenesis. J Ethnopharmacol. 1999;67(2):189-95. http://dx.doi.org/10.1016/S0378-8741(99)00015-X. PMid:10619383.

Bhatia N, Demmer TA, Sharma AK, Elcheva I, Spiegelman VS. Role of b -TrCP ubiquitin ligase receptor in UVB mediated responses in skin. Arch Biochem Biophys. 2011;508(2):178-84. http://dx.doi.org/10.1016/j.abb.2010.12.023. PMid:21187057.

Biswas K, Chattopadhyay I, Banerjee RK, Bandyopadhyay U. Biological activities and medicinal properties of neem (Azadirachta indica). Curr Sci. 2002;82(11):1336-45.

Campanini MZ, Custódio DL, Ivan ALM, Martins SM, Paranzini MJR, Martinez RM, Verri WA Jr, Vicentini FTMC, Arakawa NS, Faria TJ, Baracat MM, Casagrande R, Georgetti SR. Topical Formulations Containing Pimenta pseudocaryophyllus Extract : in vitro antioxidant activity and in vivo efficacy against UV-B-induced oxidative stress. AAPS PharmSciTech. 2014;15(1):86-95. http://dx.doi.org/10.1208/s12249-013-0049-8. PMid:24249253.

Campanini MZ, Pinho-Ribeiro FA, Ivan ALM, Ferreira VS, Vilela FMP, Vicentini FTMC, Martinez RM, Zarpelon AC, Fonseca MJ, Faria TJ, Baracat MM, Verri WA Jr, Georgetti SR, Casagrande R. Efficacy of topical formulations containing Pimenta pseudocaryophyllus extract against UVB-induced oxidative stress and inflammation in hairless mice. J Photochem Photobiol B. 2013;127:153-60. http://dx.doi.org/10.1016/j.jphotobiol.2013.08.007. PMid:24041853.

Casagrande R, Georgetti SR, Verri WA, Jabor JR, Santos AC, Fonseca MJV. Evaluation of functional stability of quercetin as a raw material and in different topical formulations by its antilipoperoxidative activity. AAPS PharmSciTech. 2006;7(1):1-8. http://dx.doi.org/10.1208/pt070110.

Champagne DE, Koul O, Isman MB, Scudder GGE, Neil Towers GH. Biological activity of limonoids from the rutales. Phytochemistry. 1992;31(2):377-94. http://dx.doi.org/10.1016/0031-9422(92)90003-9.

Di Mambro VM, Fonseca MJV. Assays of physical stability and antioxidant activity of a topical formulation added with different plant extracts. J Pharm Biomed Anal. 2005;37(2):287-95. http://dx.doi.org/10.1016/j.jpba.2004.10.030. PMid:15708669. 
El-hawary SS, El-tantawy ME, Rabeh MA, Badr WK. DNA fingerprinting and botanical study of Azadirachta indica. Beni-Suef Univ J Basic Appl Sci. 2013;2(1):1-13. http://dx.doi.org/10.1016/j.bjbas.2013.09.001.

Gautam MK, Goel S, Ghatule RR, Singh A, Joshi VK, Goel RK. Azadirachta indica Attenuates Colonic Mucosal Damage in Experimental Colitis Induced by Trinitrobenzene Sulfonic Acid. Indian J Pharm Sci. 2013;75(5):602-6. PMid:24403663.

Ghimeray AK, Jin C, Ghimire BK, Cho DH. Antioxidant activity and quantitative estimation of azadirachtin and nimbin in Azadirachta indica A. Juss grown in foothills of Nepal. Afr J Biotechnol. 2009;8(13):3084-91.

Huang ZR, Hung C, Lin Y, Fang J. In vitro and in vivo evaluation of topical delivery and potential dermal use of soy isoflavones genistein and daidzein. Int J Pharm. 2008;364(1):36-44. http://dx.doi.org/10.1016/j.ijpharm.2008.08.002. PMid:18761396.

Ichihashi M, Ueda M, Budiyanto A, Bito T, Oka M, Fukunaga M, Tsuru K, Horikawa T. UV-induced skin damage. Toxicology. 2003;189(1-2):21-39. http://dx.doi.org/10.1016/S0300-483X(03)00150-1. PMid:12821280.

Jantschko W, Furtmüller PG, Zederbauer M, Neugschwandtner K, Lehner I, Jakopitsch C, Arnhold J, Obinger $C$. Exploitation of the unusual thermodynamic properties of human myeloperoxidase in inhibitor design. Biochem Pharmacol. 2005;69(8):1149-57. http://dx.doi.org/10.1016/j.bcp.2005.02.006. PMid:15794935.

Katalinic V, Modun D, Music I, Boban M. Gender differences in antioxidant capacity of rat tissues determined by reducing antioxidant power (FRAP) assays. Comp Biochem Physiol Part C. 2005;140:47-52. PMid:15792622.

Kaura SK, Gupta SK, Chowdhury JB. Morphological and oil content variation in seeds of Azadirachta indica A. Juss. (Neem) from northern and western provenances of India. Plant Foods Hum Nutr. 1998;52(4):293-8. http://dx.doi.org/10.1023/A:1008013424150. PMid:10426116.

Kim B, Rhee J, Lee K, Kim M, Shin K, Lee S, Lee YM, Lee JS. UV-B radiation-induced oxidative stress and p38 signaling pathway involvement in the benthic copepod Tigriopus japonicus. Comp Biochem Physiol C Toxicol Pharmacol. 2015;167:15-23. PMid:25152408.

Koul O, Isman MB, Ketkar CM. Properties and uses of neem, Azadirachta indica. Can J Bot. 1990;68(1):111. http://dx.doi.org/10.1139/b90-001.

Kumazawa S, Hamasaka T, Nakayama T. Antioxidant activity of propolis of various geographic origins. Food Chem. 2004;84(3):329-39. http://dx.doi.org/10.1016/S0308-8146(03)00216-4.

Marquele-Oliveira F, Fonseca YM, De Freitas O, Fonseca MJV. Development of topical functionalized formulations added with propolis extract : Stability, cutaneous absorption and in vivo studies. Int J Pharm. 2007;342(1-2):40-8. http://dx.doi.org/10.1016/j.ijpharm.2007.04.026. PMid:17600647.

Martinez RM, Hohmann MS, Longhi-Balbinot DT, Zarpelon AC, Baracat MM, Georgetti SR, Vicentini FTMC, Sassonia RC, Verri WA Jr, Casagrande R. Analgesic activity and mechanism of action of a Beta vulgaris dye enriched in betalains in inflammatory models in mice. Inflammopharmacology. 2020. In press. http://dx.doi.org/10.1007/s10787-020-00689-4. PMid:32141011.

Martinez RM, Pinho-Ribeiro FA, Steffen VS, Caviglione CV, Vignoli JA, Barbosa DS, Baracat MM, Georgetti SR, Verri WA Jr, Casagrande R. Naringenin Inhibits UVB Irradiation-Induced Inflammation and Oxidative Stress in the Skin of Hairless Mice. J Nat Prod. 2015;78(7):1647-55. http://dx.doi.org/10.1021/acs.jnatprod.5b00198. PMid:26154512.

Martinez RM, Pinho-ribeiro FA, Steffen VS, Caviglione CV, Pala D, Baracat MM, Georgetti SR, Verri WA, Casagrande R. Topical formulation containing hesperidin methyl chalcone inhibits skin oxidative stress and inflammation induced by ultraviolet B irradiation. Photochem Photobiol Sci. 2016a;15(4):554-63. http://dx.doi.org/10.1039/C5PP00467E. PMid:27021784.

Martinez RM, Pinho-Ribeiro FA, Steffen VS, Silva TCC, Caviglione CV, Bottura C, Fonseca MJ, Vicentini FT, Vignoli JA, Baracat MM, Georgetti SR, Verri WA Jr, Casagrande R. Topical formulation containing naringenin : efficacy against Ultraviolet B Irradiation- induced skin inflammation and oxidative stress in mice. PLoS One. 2016b;2(1): e0146296. http://dx.doi.org/10.1371/journal.pone.0146296. PMid:26741806.

Martinez RM, Pinho-Ribeiro FA, Vale DL, Steffen VS, Vicentini FTMC, Vignoli JA, Baracat MM, Georgetti SR, Verri WA Jr, Casagrande R. Trans-chalcone added in topical formulation inhibits skin inflammation 
and oxidative stress in a model of ultraviolet B radiation skin damage in hairless mice. J Photochem Photobiol B. 2017;171:139-46. http://dx.doi.org/10.1016/j.jphotobiol.2017.05.002. PMid:28501692.

Martinez RM, Zarpelon AC, Zimermann VVM, Georgetti SR, Baracat MM, Fonseca MJV, Vicentini FTMC, Moreira IC, Andrei CC, Verri WA Jr, Casagrande R. Tephrosia sinapou extract reduces inflammatory leukocyte recruitment in mice: effect on oxidative stress, nitric oxide and cytokine production. Rev Bras Farmacogn. 2012;22(3):587-97. http://dx.doi.org/10.1590/S0102-695X2012005000006.

Moneim AEA, Othman MS, Aref AM. Azadirachta indica attenuates cisplatin-induced nephrotoxicity and oxidative stress. BioMed Res Int. 2014;2014:1-11. http://dx.doi.org/10.1155/2014/647131. PMid:25162019.

Park YK, Alencar SM, Aguiar CL. Botanical origin and chemical composition of Brazilian propolis. J Agric Food Chem. 2002;50(9):2502-6. http://dx.doi.org/10.1021/jf011432b. PMid:11958612.

Rastogi RP, Richa, Kumar A, Tyagi MB, Sinha RP. Molecular mechanisms of ultraviolet radiation-induced DNA damage and repair. J Nucleic Acids. 2010;2010:1-32. http://dx.doi.org/10.4061/2010/592980. PMid:21209706.

Sánchez-González I, Jiménez-Escrig A, Saura-Calixto F. In vitro antioxidant activity of coffees brewed using different procedures (Italian, espresso and filter). Food Chem. 2005;90(1-2):133-9. http://dx.doi.org/10.1016/j.foodchem.2004.03.037.

Siddiqui BS, Ghiasuddin, Faizi S, Siddiqui S. Ghiasuddin, Faizi S, Siddiqui S. Triterpenoids from the fresh fruit coats of Azadirachta indica. Phytochemistry. 1992;31(12):4275-8. http://dx.doi.org/10.1016/0031-9422(92)80457-P.

Sonika G, Manubala R, Deepak J. Comparative studies on anti-inflammatory activity of Coriandrum Sativum, Datura stramonium and Azadirachta Indica. Asian J Exp Biol Sci. 2010;1(1):151-4.

Sultana B, Anwar F, Przybylski R. Antioxidant activity of phenolic components present in barks of Azadirachta indica, Terminalia arjuna, Acacia nilotica, and Eugenia jambolana Lam. trees. Food Chem. 2007;104(3):1106-14. http://dx.doi.org/10.1016/j.foodchem.2007.01.019.

Valko M, Leibfritz D, Moncol J, Cronin MTD, Mazur M, Telser J. Free radicals and antioxidants in normal physiological functions and human disease. Int J Biochem Cell Biol. 2007;39(1):44-84. http://dx.doi.org/10.1016/j.biocel.2006.07.001. PMid:16978905.

van der Nat JM, van der Sluis WG, de Silva KTD, Labadie RP. Ethnopharmacognostical survey of Azadirachita indica A. Juss (Meliaceae). J Ethnopharmacol. 1991;35(1):1-24. http://dx.doi.org/10.1016/0378-8741(91)90131-V. PMid:1753794.

Vicentini FTMC, Simi TR, Del Ciampo JO, Wolga NO, Pitol DL, Iyomasa MM, Bentley MV, Fonseca MJ. Quercetin in w/o microemulsion : in vitro and in vivo skin penetration and efficacy against UVBinduced skin damages evaluated in vivo. Eur J Pharm Biopharm. 2008;69(3):948-57. http://dx.doi.org/10.1016/j.ejpb.2008.01.012. PMid:18304790.

Witko-Sarsat V, Rieu P, Descamps-Latscha B, Lesavre P, Halbwachs-Mecarelli L. Neutrophils: molecules, functions and pathophysiological aspects. Lab Invest. 2000;80(5):617-53.

http://dx.doi.org/10.1038/labinvest.3780067. PMid:10830774.

\section{Author contributions}

RMM and CRS: performing experiments and data aquisition;

CPBM: In vivo experiments, wrinting;

MMB, NSA and JCD: data curation, formal analysis;

WAVJr; RC and SRG: Funding acquisition, Conceptualization, Experimental design, Project administration, formal analysis, writing. 